Article

\title{
Investigating the Electrochemical Interaction of a Thiol Collector with Chalcopyrite and Galena in the Presence of a Mixed Microbial Community
}

\author{
Ngoni Mhonde ${ }^{1, *}$, Mariette Smart ${ }^{2}\left(\mathbb{D}\right.$, Kirsten Corin $^{3}{ }^{-1}$ and Nora Schreithofer ${ }^{1}$ \\ 1 Department of Bioproducts and Biosystems, School of Chemical Engineering, Aalto University, \\ Vuorimiehentie 1, 00076 Espoo, Finland; nora.schreithofer@aalto.fi \\ 2 Centre for Bioprocess Engineering, Chemical Engineering Department, University of Cape Town, P Bag X3, \\ Rondebosch 7701, Cape Town, South Africa; mariette.smart@uct.ac.za \\ 3 Centre for Minerals Research, Chemical Engineering Department, University of Cape Town, P Bag X3, \\ Rondebosch 7701, Cape Town, South Africa; kirsten.corin@uct.ac.za \\ * Correspondence: ngoni.mhonde@aalto.fi
}

Received: 11 May 2020; Accepted: 18 June 2020; Published: 19 June 2020

\begin{abstract}
High microbial cell counts have been recorded in sewage waters employed as process water in mineral beneficiation plants across the world. The presence of these microbes can negatively impact flotation performance through mineral passivation, although some microbes improve flotation performance as investigated in various bio-flotation studies. The current study aims to understand the electrochemical behaviour of minerals in the presence of a sodium ethyl xanthate (SEX) collector and microbes originating from a sulphide ore processing plant in South Africa. The electrochemical response was correlated to observe flotation performance. Mixed potential measurements were conducted in parallel to microflotation tests, to assess the hydrophilicity or hydrophobicity induced on sulphide minerals adapted to microbe-laden synthetic plant water. Sulphide minerals' mixed potentials and interactions of SEX with sulphide minerals were dramatically reduced in the presence of the mixed microbial community (MMC). The observations were correlated with poor flotation efficacy noted in microflotation tests. These fundamental results shed light on how the adsorption of thiol collectors on sulphide minerals is adversely affected by microbes, prompting a discussion on flotation process monitoring when mineral beneficiation is conducted using microbe-laden water.
\end{abstract}

Keywords: electrochemistry; microbes; microflotation; recovery; adhesion; zeta potential

\section{Introduction}

The use of raw or partially remediated, sewage effluent water (grey water) for the flotation beneficiation of minerals has become increasingly popular. Sewage water serves to limit the mining industry's dependence on freshwater sources, which could alternatively be channelled towards other economic and societal activities that require significantly higher water quality levels in comparison to mineral beneficiation. A case in point is a platinum mine located in the dry and arid northern part of South Africa, where sewage water is the main source of process water employed in the flotation circuit. However, the use of sewage water introduces multiple microbial species and nutrients supportive of microbial growth into the process water stream. In addition to incoming sewage water, the microbes found in process plant water originate from recirculated tailings pond water and mineral surfaces. When microbes are present in a flotation circuit, they can act as surface modifiers, collectors or depressants, attaching onto minerals and rendering them hydrophilic or hydrophobic [1-4].

Microbes and their metabolic products are also known to have some surface active properties, hence, there is a possibility of them influencing frothing properties in the flotation circuit [5]. Frothing is 
mainly affected by microbes and organic acids present in solution. These biotic water constituents contribute significantly to the total organic carbon (TOC) content in sewage water. High TOC contents have been reported to cause excessive frothing, which adversely affects the efficiency of the cleaners in the flotation circuit [6]. The efficiency of cleaners inherently affects mineral separation through microbial consumption of xanthate (reagents) and oxygen [5,7]. Xanthate consumption occurs when bacteria use xanthate molecules' sulphur sites as growth substrates, which depletes the xanthate in the process [8]. Xanthates and oxygen are important constituents which facilitate the desired sulphide mineral separation during flotation. Without these constituents, the flotation separation of sulphide ores is rendered unsuccessful.

Microbes, although overlooked by metallurgists, significantly affect mineral beneficiation through alterations in solution chemistry and reagent-mineral surface reactions. In a paper by Levay et al. [9], the authors reported that microbial action in flotation circuits can cause dramatic changes in the solution chemical conditions, which can have a far reaching effect on reagent efficacy. $\mathrm{pH}$ values can change from 9.5 to $<3$ and $\mathrm{Eh}$ from $+400 \mathrm{mV}$ to $<-200 \mathrm{mV}$ for water stored over periods between 4 and $40 \mathrm{~d}$. Evdokimova et al. [10] stated that the ambient temperature significantly affects microbial activity in flotation circuits. Plant surveys on an apatite processing mine in Russia revealed that high bacterial cell counts in recirculated plant water were most prevalent in the warmer spring and summer months. The circulated water temperatures ranged from $+2{ }^{\circ} \mathrm{C}$ to $+16^{\circ} \mathrm{C}$, and the summer survey recorded microbial concentrations of $3 \times 10^{7}$ cells $/ \mathrm{mL}$ in comparison to the winter survey, where bacterial concentrations were nearly tenfold lower at $5 \times 10^{6}$ cells $/ \mathrm{mL}$. Microbial interactions with elements within the flotation circuit tend to alter reaction conditions. The abundance of these microbes in plant water determines the extent to which mineral beneficiation is affected.

The interaction of acidophilic microorganisms with sulphide minerals is well established in the biohydrometallurgy space. Several studies have reported on bacterial action of minerals in bacterial aided mineral leaching and microbial bio-oxidation of exposed sulphide tailings, leading to acid mine drainage formation [11-15]. Initial adhesion of microbes on mineral surfaces has been postulated to occur through the combined effect of long-range and short-range attraction forces. Electrostatic interactions, the effect of weak van der Waals forces described under the Derjaguin-Landau-Verwey-Overbeek (DLVO) theory and hydrophobic interactions have been proposed to be responsible for initial reversible adhesion [16,17]. However, even when both the microbes and the mineral surface are negatively charged, attachment still occurs as confirmed by changes in mineral surface potential. Hydrophobic interactions and mild bio-oxidation over electrostatic interactions are thus favoured as the initial attachment mechanism for both sulphide and non-sulphide minerals [18,19]. There is much disagreement in the literature as to which mechanism is most responsible for the attachment of microbes onto sulphide minerals. Despite the disagreement on the finer details of adsorption mechanisms, the literature generally agrees that initial adsorption of microbes on minerals begins with a reversible adhesion stage. This is followed by firm adsorption facilitated by an extracellular polymeric substance (EPS) and subsequently, over long periods of microbial action on the mineral surfaces (i.e., from days to weeks), the formation of a thin biofilm layer completes microbial adsorption on the minerals $[14,20,21]$. What is certain is that the adhesion of microbes on mineral surfaces inherently leads to alterations in the minerals' physicochemical properties. Microbes also induce changes in solution chemistry, which can either negatively affect collector adsorption efficacy on minerals or enhance flotation of some minerals.

The adsorption of thiol collectors on sulphide minerals is controlled by an electrochemical oxidation-reduction reaction occurring at the sulphide mineral surface [22-27]. Thiol collector adsorption has been generally accepted to occur in one or all of three oxidation routes: oxidative chemisorption according to Equation (1); an oxidation reaction between the thiolate ion and a metal-rich surface, forming a metal thiolate according to Equation (2); the formation of a dithiolate that 
is physisorbed on the mineral surface as described in Equation (3). The counter reduction reaction which occurs through the cathodic reduction of oxygen is presented in Equation (4).

$$
\begin{gathered}
\mathrm{X}_{\text {ads }}+\mathrm{e}^{-}=\mathrm{X}^{-} \\
\mathrm{M}^{2+}+2 \mathrm{X}^{-}=\mathrm{MX}_{2} \\
\mathrm{X}_{2 \mathrm{ads}}+2 \mathrm{e}^{-}=2 \mathrm{X}^{-} \\
\mathrm{O}_{2}+2 \mathrm{H}_{2} \mathrm{O}+4 \mathrm{e}^{-}=4 \mathrm{OH}^{-}
\end{gathered}
$$

The combined anodic oxidation of the collector, oxidation of mineral surfaces and cathodic reduction of oxygen, create a potential at the mineral surface referred to as the mixed potential (rest potential). The mixed potential of a sulphide mineral surface may be affected by solution chemical conditions in several ways. For example, Allison [1] showed that mixed potential values of a wide range of tested sulphide minerals all differed in the presence and absence of a xanthate collector. Mixed potentials of minerals in collectorless solutions were lowered once a collector (xanthate at $2.5 \times 10^{-4} \mathrm{M}$ ) was added to the mineral system, and the authors concluded that this was a result of collector interaction with sulphide minerals [24,28]. The rest potential theory is also used as a means of predicting the species of the adsorbed collector on the mineral surface. Either dixanthogen or the metal thiolate, and in some cases a combination of both collector species, form on the sulphide mineral surface $[28,29]$. A positive rest potential with respect to the dixanthogen couple $\left(\mathrm{X}^{-} / \mathrm{X}_{2}\right)$ line alludes to the formation of dixanthogen on the mineral surface, whereas a final rest potential below the dixanthogen couple line is indicative of the presence of a metal thiolate on the mineral surface [29]. Recently, the mixed potential theory of mineral surfaces has been used to show microbial attachment onto pyrite [30-32]. However, what is lacking from these studies is the extent to which the mixed potential of the mineral system is affected in the presence of both microbes and collectors. Therefore, the current study attempts to understand the mixed potentials of galena and chalcopyrite when simultaneously exposed to microbes and collectors (xanthates).

It is against this background that interest in understanding xanthate and sulphide mineral electrochemical responses in the presence of microbes was born. The current study attempts to understand the mixed potentials of galena and chalcopyrite when exposed to microbes and thiol collectors. The electrochemical results are supported by surface characterisation using zeta potential measurements and microflotation tests. Most studies have only investigated a model microbe; however, plant water is laden with multiple communities of microbes which may behave differently in their interactions with the minerals at the solid-liquid interface. The current study follows a more realistic approach to flotation-related microbial studies, employing a mixed microbial community (MMC) originating from plant waters of a platinum mine in South Africa.

\section{Materials and Methods}

\subsection{Materials and Reagents}

\subsubsection{Mineral Preparation}

High purity chalcopyrite and galena used in microflotation tests were received from Ward's Natural Science Establishment (Rochester, NY, USA) in chunks. The chunks were hammered down and pulverized for $20 \mathrm{~s}$ using a laboratory scale pulverizer. The resultant fine powder was sieved to obtain two size fractions of $<38 \mu \mathrm{m}$ and 38-108 $\mu \mathrm{m}$. The samples were then purged with nitrogen and stored in the freezer at $-15{ }^{\circ} \mathrm{C}$ until used. The $<38 \mu \mathrm{m}$ size fraction was reserved for use in zeta potential tests, whilst the 38-108 $\mu \mathrm{m}$ was employed in microflotation studies. Before any tests were conducted, a magnet was used to remove magnetic material in the ore, which would otherwise stick to magnetic stirring bars, resulting in incorrect mass balances during microflotation tests. 


\subsubsection{Reagents}

The sodium ethyl xanthate (SEX) used in the experiments (99\% purity) was sourced from Senmin. For microflotation tests, the collector dosage was based on the active collector content and Brunauer-Emmett-Teller (BET) surface areas of the minerals under investigation. Adsorption of gas molecules on the mineral surface was used as a basis to estimate the mineral surface area. A 50\% pseudo-monolayer coverage dosage was used since it was previously shown that at this monolayer coverage, the collector molecules interact directly with the mineral surface instead of intramolecular interactions between collector molecules [33]. Table 1 shows the measured BET surface areas for the mineral samples used in the microflotation tests. It was also assumed that the cross-sectional area of a thiol collector molecule head was approximately $28.8 \AA$ [34].

Table 1. Brunauer-Emmett-Teller (BET) surface area of 38-108 $\mu \mathrm{m}$ size fraction of minerals used in microflotation tests.

\begin{tabular}{cc}
\hline Mineral & BET Surface Area $\left(\mathrm{m}^{2} / \mathrm{g}\right)$ \\
\hline Chalcopyrite & 0.2327 \\
\hline Galena & 0.0688 \\
\hline
\end{tabular}

A $1 \%(w / v)$ stock solution of SEX was prepared by dissolving $0.5 \mathrm{~g}$ of SEX in $50 \mathrm{~mL}$ of deionized water. The required volume of $1 \%$ SEX stock solution was drawn and added to the electrochemical cell to make up a SEX concentration of $2.4 \times 10^{-4} \mathrm{~mol} / \mathrm{L}$ in solution during open circuit potential measurements. Deionized water used in the electrochemical cell was altered by addition of sodium sulphate $\mathrm{Na}_{2} \mathrm{SO}_{4}$ to produce a $0.1 \mathrm{~mol} / \mathrm{L} \mathrm{Na}_{2} \mathrm{SO}_{4}$ electrolyte solution. Sodium tetraborate decahydrate $\mathrm{Na}_{2} \mathrm{~B}_{4} \mathrm{O}_{7} \cdot 10 \mathrm{H}_{2} \mathrm{O}$ was also added to the deionized water to create a $0.05 \mathrm{~mol} / \mathrm{L} \mathrm{Na}{ }_{2} \mathrm{~B}_{4} \mathrm{O}_{7} \cdot 10 \mathrm{H}_{2} \mathrm{O}$ buffer solution of $\mathrm{pH} 9.3$.

\subsubsection{Microbial Cell Growth and Preparation}

An MMC originating from the concentrator waters of a platinum mine in South Africa was used for this study. The concentrations of ions in process water as reported by Wiese et al. [35] and Manono et al. [36] are presented in Table 2. The microbes were originally harvested from process plant water by washing the microbes from the mineral fractions across different circuit waters with a $0.4 \%(v / v)$ Tween solution prepared in $1 \times$ phosphate-buffered saline (PBS; $8 \mathrm{~g} / \mathrm{L} \mathrm{NaCl}, 0.2 \mathrm{~g} / \mathrm{L} \mathrm{KCl}$, $\left.1.44 \mathrm{~g} / \mathrm{L} \mathrm{Na}_{2} \mathrm{HPO}_{4}, 0.24 \mathrm{~g} / \mathrm{L} \mathrm{KH}_{2} \mathrm{PO}_{4}\right) \mathrm{pH}$ 7.4. The MMC was cultured in a medium containing $1 \times \mathrm{PBS}$, $0.1 \%(w / v)$ yeast extract and $1 \times$ trace elements $\left(1000 \times\right.$ solution contained: $10 \mathrm{~g} / \mathrm{L} \mathrm{ZnSO}{ }_{4} \cdot 7 \mathrm{H}_{2} \mathrm{O} ; 10 \mathrm{~g} / \mathrm{L}$ $\mathrm{FeSO}_{4} \cdot 7 \mathrm{H}_{2} \mathrm{O} ; 1 \mathrm{~g} / \mathrm{L} \mathrm{CuSO}{ }_{4} \cdot 5 \mathrm{H}_{2} \mathrm{O} ; 1 \mathrm{~g} / \mathrm{L} \mathrm{MnSO}_{4} \cdot 4 \mathrm{H}_{2} \mathrm{O} ; 1 \mathrm{~g} / \mathrm{L} \mathrm{CoSO}_{4} \cdot 7 \mathrm{H}_{2} \mathrm{O} ; 0.5 \mathrm{Cr}_{2}\left(\mathrm{SO}_{4}\right)_{3} \cdot 15 \mathrm{H}_{2} \mathrm{O} ; 0.6 \mathrm{~g} / \mathrm{L}$ $\left.\mathrm{H}_{3} \mathrm{BO}_{3} ; 0.5 \mathrm{~g} / \mathrm{L} \mathrm{Na}_{2} \mathrm{MoO}_{4} \cdot 2 \mathrm{H}_{2} \mathrm{O} ; 1 \mathrm{~g} / \mathrm{L} \mathrm{NiSO}_{4} \cdot 6 \mathrm{H}_{2} \mathrm{O} ; 1 \mathrm{~g} / \mathrm{L} \mathrm{Na}_{2} \mathrm{SeO}_{4} \cdot 10 \mathrm{H}_{2} \mathrm{O} ; 0.1 \mathrm{~g} / \mathrm{L} \mathrm{Na}_{2} \mathrm{WO}_{4} \cdot 2 \mathrm{H}_{2} \mathrm{O}\right)$. Microbes were cultured on a rotary shaker $(140 \mathrm{rpm})$ at $37^{\circ} \mathrm{C}$ for $16 \mathrm{~h}$. The microbial cells were then harvested by centrifugation at $17,700 \times \mathrm{g}$ for $10 \mathrm{~min}$ using a Beckman Coulter centrifuge. The cells were washed twice with deionized water or $1 \times$ PBS before suspension in the deionized water or $1 \times$ PBS depending on the experiment to be conducted. The bacterial cell count was determined through direct microscopic counting using a Thoma counting chamber and a phase contrast Olympus BX-40 microscope at $15,000 \times$ magnification.

Table 2. Physicochemical properties of a typical South African platinum mine processing plant water.

\begin{tabular}{ccccccccc}
\hline \multicolumn{7}{c}{ Ion Concentrations (ppm) } \\
\hline $\mathrm{Ca}^{2+}$ & $\mathrm{Mg}^{2+}$ & $\mathrm{Na}^{+}$ & $\mathrm{Cl}^{-}$ & $\mathrm{SO}_{4}{ }^{2-}$ & $\mathrm{NO}_{3}{ }^{-}$ & $\mathrm{CO}_{3}{ }^{2-}$ & $\mathrm{pH}$ & $\mathrm{Temp}{ }^{\circ} \mathrm{C}$ \\
\hline 80 & 70 & 153 & 287 & 240 & 176 & 17 & $9-9.5$ & $25-35$ \\
\hline
\end{tabular}




\subsection{Zeta Potential Measurements}

Zeta potential tests were conducted using a Malvern zeta sizer. Zeta potentials of particles in a liquid medium were measured by means of a $633 \mathrm{~nm}$ laser beam. The ideal particle size range suitable for zeta potential measurements is $5 \mathrm{~nm}-10 \mu \mathrm{m}$. The machine was equipped with software to trace and process the movement of ultrafine particles within the liquid suspension. Zeta potential measurements were recorded for the microbes, the pure mineral sample and the mineral sample conditioned with microbes. For each of the previously mentioned conditions, 6 beakers containing deionized water and $80 \mathrm{mg}$ of mineral were prepared. The mixture was sonicated to remove agglomerates then the mixtures' $\mathrm{pH}$ was adjusted to the desired $\mathrm{pH}$. $\mathrm{pH}$ values of 2, 4, 6, 8, 10 and 12 were investigated for zeta potential measurements. All measurements were completed with $\mathrm{KNO}_{3}$ as an indifferent electrolyte at a concentration of $0.001 \mathrm{M}$. Conditioning of the minerals in deionized water and microbes $\left(1 \times 10^{8}\right.$ cells $\left./ \mathrm{mL}\right)$ was carried out for $20 \mathrm{~min}$. After conditioning, the mixtures were allowed to settle for $10 \mathrm{~min}$ before a 2-3 $\mathrm{mL}$ aliquot of the supernatant was drawn and transferred to the Malvern for zeta potential measurements. All tests were performed in triplicate to ensure reproducibility.

\subsection{Rest Potential Measurements}

Rest potential measurements were conducted under four experimental conditions: in the absence of both microbes and xanthate; in the presence of xanthate only; the addition of SEX followed by the addition of microbes; the addition of microbes followed by SEX. Microbes were added to a final cell concentration of $1 \times 10^{8}$ cells/mL. Two minerals were tested viz chalcopyrite and galena. A full description of the mineral electrode construction is provided by Tadie et al. [37]. A three-electrode electrochemical cell was used with the mineral electrode acting as the working electrode and the $\mathrm{Ag} / \mathrm{AgCl}$ electrode acting as a reference electrode. The recorded mixed potentials were adjusted by adding $0.207 \mathrm{~V}$ to the recorded value as the $\mathrm{Ag} / \mathrm{AgCl}$ electrode's measured potential was $+0.207 \mathrm{vs}$. the platinum standard hydrogen electrode (SHE). Before rest potential measurements were recorded, the mineral surface was first polished using 600 grit silicon carbide paper, followed by finer polishing using $1.0 \mu \mathrm{m}, 0.3 \mu \mathrm{m}$ and $0.05 \mu \mathrm{m}$ alumina powders sourced from IMP Scientific and Precision (Pty) Ltd. (Boksburg, South Africa). Deionized water was used to rinse the mineral surface followed by drying through lightly dabbing the mineral surface with a paper towel. Rest potentials were then controlled and measured under the desired conditions using a Gamry 3000 potentiostat (Gamry Instruments Inc, Pennsylvania, USA) and Gamry Framework computer software (version 7). Rest potentials were measured in the absence of reagents for $300 \mathrm{~s}$ allowing the surface to equilibrate, then SEX or microbes were added, and rest potentials were measured for $300 \mathrm{~s}$ before a final addition of microbes or SEX at $600 \mathrm{~s}$.

\subsection{Microflotation Tests}

A University of Cape Town microflotation rig as described by Bradshaw and Connor [38], was used to conduct microflotation tests with the aim of understanding the extent of mineral hydrophobicity in the presence of microbes. First, $50 \mathrm{~mL}$ of deionized water were added to previously weighed $2 \mathrm{~g}$ of mineral sample, and the mixture was sonicated for $5 \mathrm{~min}$ to disperse the particles in the slurry. Harvested microbes were added, and the slurry was conditioned by stirring using a magnetic stirrer for $30 \mathrm{~min}$. Two microbial concentrations $\left(1 \times 10^{8}\right.$ cells $/ \mathrm{mL}$ and $4 \times 10^{8}$ cells $\left./ \mathrm{mL}\right)$ were investigated. These microbial concentrations were chosen based on previous experimental and site survey microbial cell counts observed in the literature. Liu et al. [20] showed that chalcopyrite hydrophobicity is only significantly affected at microbial concentrations greater than $5 \times 10^{7}$ cells $/ \mathrm{mL}$. Plant survey results by Levay et al. [9] also showed that depending on the site, microbial cell counts in process water can range as high as $1 \times 10^{8}-1 \times 10^{9} \mathrm{cfu} / \mathrm{mL}$, where cfu represents the colony forming units (available viable cells). The required SEX dosage based on a $50 \%$ pseudo-monolayer coverage was added to the slurry and conditioning proceeded for $3 \mathrm{~min}$. After $\mathrm{pH}$ adjustment to $\mathrm{pH} 9.3$, the slurry was transferred to the 
microflotation cell. Made up deionized water was added to the cell until the required water level was attained. Air at a flowrate of $8 \mathrm{~L} / \mathrm{min}$ was introduced at the bottom of the cell using a peristaltic pump, attached to an injection needle. Concentrates were then collected at 2, 6, 12 and 20 min of flotation. The concentrates were filtered using a MN615 grade cellulose filter paper with a thickness of $0.16 \mathrm{~mm}$ and a pore size of 4-12 $\mu \mathrm{m}$. The filter paper was manufactured by Macherey-Nagel (Duren, Germany). After filtration, the solid mass was dried in the oven at $70{ }^{\circ} \mathrm{C}$ before the final weighing.

\section{Results and Discussion}

\subsection{Zeta Potential Measurements on Sulphide Minerals in the Presence and Absence of Microbes}

The zeta potentials of the microbial suspension at an initial cell concentration of $1 \times 10^{8}$ cells $/ \mathrm{mL}$, sulphide minerals and sulphide minerals after interaction with the microbial suspension are illustrated in Figure 1; Figure 2. The zeta potentials under all three conditions were negative throughout the $\mathrm{pH}$ range (2-12) tested. Standard errors were less than 5\%, hence, the error bars are small and not clearly visible. The low solid/liquid ratio employed in the study may have resulted in the isoelectronic point falling to such low $\mathrm{pH}$ values for the sulphide minerals [39].

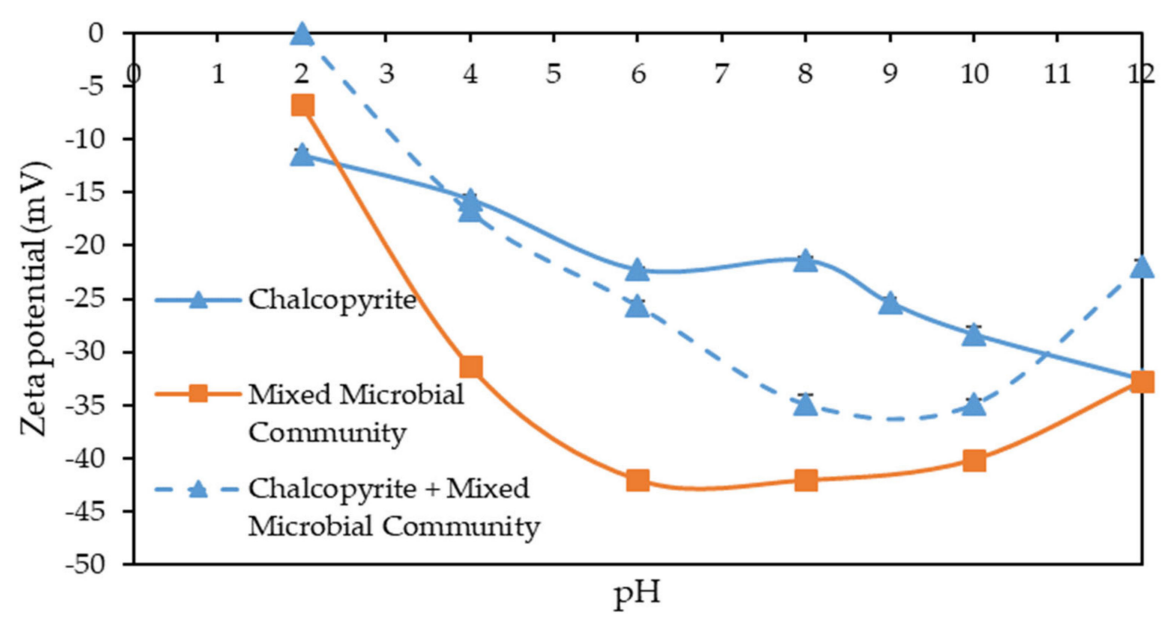

Figure 1. Zeta potentials of chalcopyrite, microbes and chalcopyrite after interaction with $1 \times 10^{8}$ cells $/ \mathrm{mL}$ of mixed microbial community.

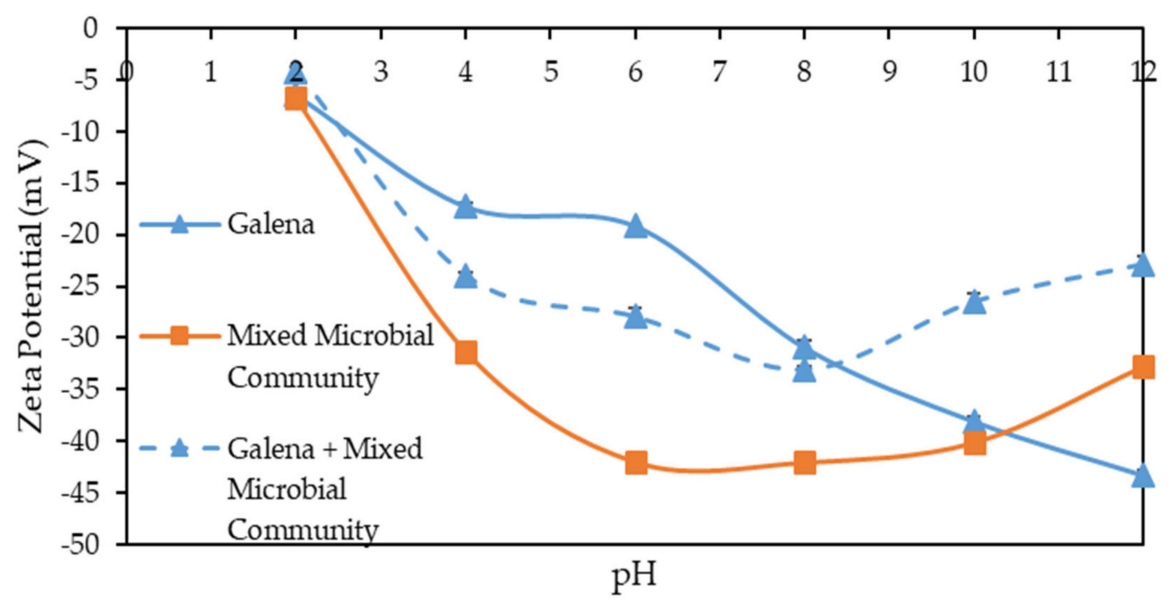

Figure 2. Zeta potentials of galena, microbes and galena after interaction with $1 \times 10^{8}$ cells $/ \mathrm{mL}$ of mixed microbial community. 
The microbial suspension also exhibited an isoelectronic point below $\mathrm{pH} 2$ (Figure 1; Figure 2). Negative zeta potentials displayed by the microbial suspensions are due to the presence of negatively charged functional groups, such as carboxyl $(-\mathrm{COOH})$, amino $\left(-\mathrm{NH}_{2}\right)$ and hydroxyl $(-\mathrm{OH})$, which form part of lipopolysaccharides, lipoproteins and surface proteins of microbial cell walls [40]. This result agreed with the low isoelectronic points recorded for various microbes investigated in previous studies [19,39-42]. Most microbes exhibited isoelectronic points around $\mathrm{pH}$ 3 or lower. An isoelectronic point below $\mathrm{pH} 2$, for microbial suspensions, is indicative of a higher concentration of polysaccharide related carboxyl groups in comparison to proteins, whereas microbes with an isoelectronic point greater than $\mathrm{pH} 3$ consist of cell wall structures abundant in protein-based molecules [43]. Surface hydrophobicity depends on the presence of functional groups on the cell wall surface. Microbes with a high concentration of polysaccharides tend to induce hydrophilicity on the mineral surface [44].

From Figure 1; Figure 2, the minerals do not exhibit any isoelectronic point. Interaction of microbial suspension with the mineral surface resulted in chalcopyrite exhibiting an isoelectronic point close to $\mathrm{pH} 2$ only after conditioning with microbes (Figure 1). A shift in the isoelectronic points after interaction with the microbial suspension may be attributed to the specific adsorption of microbial constituents onto the mineral surface due to chemical interactions [42,44]. From Figure 1; Figure 2, it is evident that adhesion occurred even though the potential on the surface of the microbial cells and the sulphide minerals was the same. These results, therefore, eliminate electrostatic interactions as a mechanism responsible for the microbial adhesion of these microbes onto the sulphide mineral surfaces.

Under acidic conditions $(\mathrm{pH}<3)$, the zeta potential of the sulphide minerals in the presence of microbes is less negative and this phenomenon is more evident for chalcopyrite than galena. Santhiya et al. [42] noticed significant changes to the zeta potentials of sphalerite and galena after just one hour of conditioning the minerals in a cell suspension of Acidithiobacillus thiooxidans. Their study proposed that the reduction in electronegativity of the zeta potential of sulphide minerals under investigation was caused by the presence of amide groups within the cell structure of the microbes, without any explanation for the possible adhesion mechanism. It must be stated that Acidithiobacillus thiooxidans are acidophilic and would likely not be present in our microbial suspension, since it was cultured under neutral conditions. However, the microbial suspension used in the current study also showed similar behaviour to that exhibited by Acidithiobacillus thiooxidans regarding zeta potential values at low $\mathrm{pH}$. One possible mechanism to explain this observation, is interaction through protonation of the microbes' amino and amide functional groups in acidic conditions, creating positively charged functional groups that subsequently attach to the negatively charged mineral surface [44]. Despite varying opinions regarding the cause of microbe-mineral interaction and resultant changes in mineral surface properties, what is certain is that there is a change in mineral surface charge when mineral surfaces are exposed to the microbial suspension.

\subsection{Rest Potential Measurements for Sulphide Minerals in the Presence of Microbes}

\subsubsection{Rest Potential Measurements for Chalcopyrite in the Presence and Absence of Microbes}

The results from the measurement of mixed potentials in the presence and absence of microbes are presented in Figure 3; Figure 4. From Figure 3, the rest potential of chalcopyrite in the absence of collector and microbes is about $170 \mathrm{mV}$ at the tested conditions. The introduction of the collector, SEX, reduces the mixed potential to $150 \mathrm{mV}$, a $20 \mathrm{mV}$ drop. The slope of the response indicates an initial sharp drop in mixed potential followed by a gradual rise in potential until a final mixed potential of $150 \mathrm{mV}$ is obtained. The final mixed potential is close to that reported by Allison et al. [29], a mixed potential of $140 \mathrm{mV}$, for chalcopyrite in the presence of SEX under similar test conditions. As mentioned in the introduction, when a sulphide mineral's final rest potential in the presence of xanthate lies above the $\mathrm{X}^{-} / \mathrm{X}_{2}$ line, the thermodynamically favoured species present on the mineral surface is dixanthogen. 
Otherwise, if the final rest potential lies well below the $\mathrm{X}^{-} / \mathrm{X}_{2}$ line, the metal thiolate is assumed to prevail as the adsorbed xanthate species.

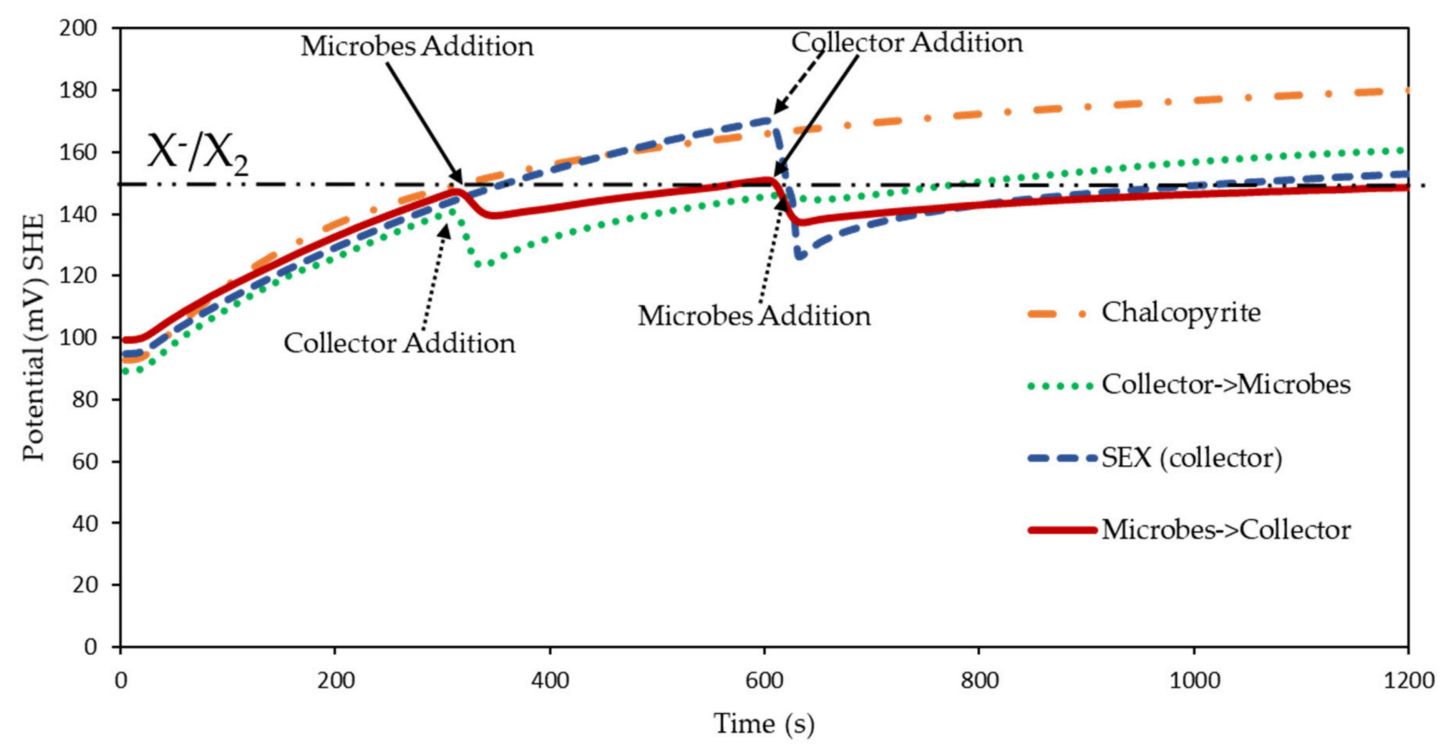

Figure 3. Mixed potential of chalcopyrite in the presence of $2.4 \times 10^{-4} \mathrm{~mol} / \mathrm{L}$ a sodium ethyl xanthate $(\mathrm{SEX}), 1 \times 10^{8}$ cells/mL microbes, $0.1 \mathrm{M} \mathrm{Na}_{2} \mathrm{SO}_{4}$ and $0.05 \mathrm{M} \mathrm{Na}_{2} \mathrm{~B}_{4} \mathrm{O}_{7}(\mathrm{pH} 9.3)$ at $25^{\circ} \mathrm{C}$.

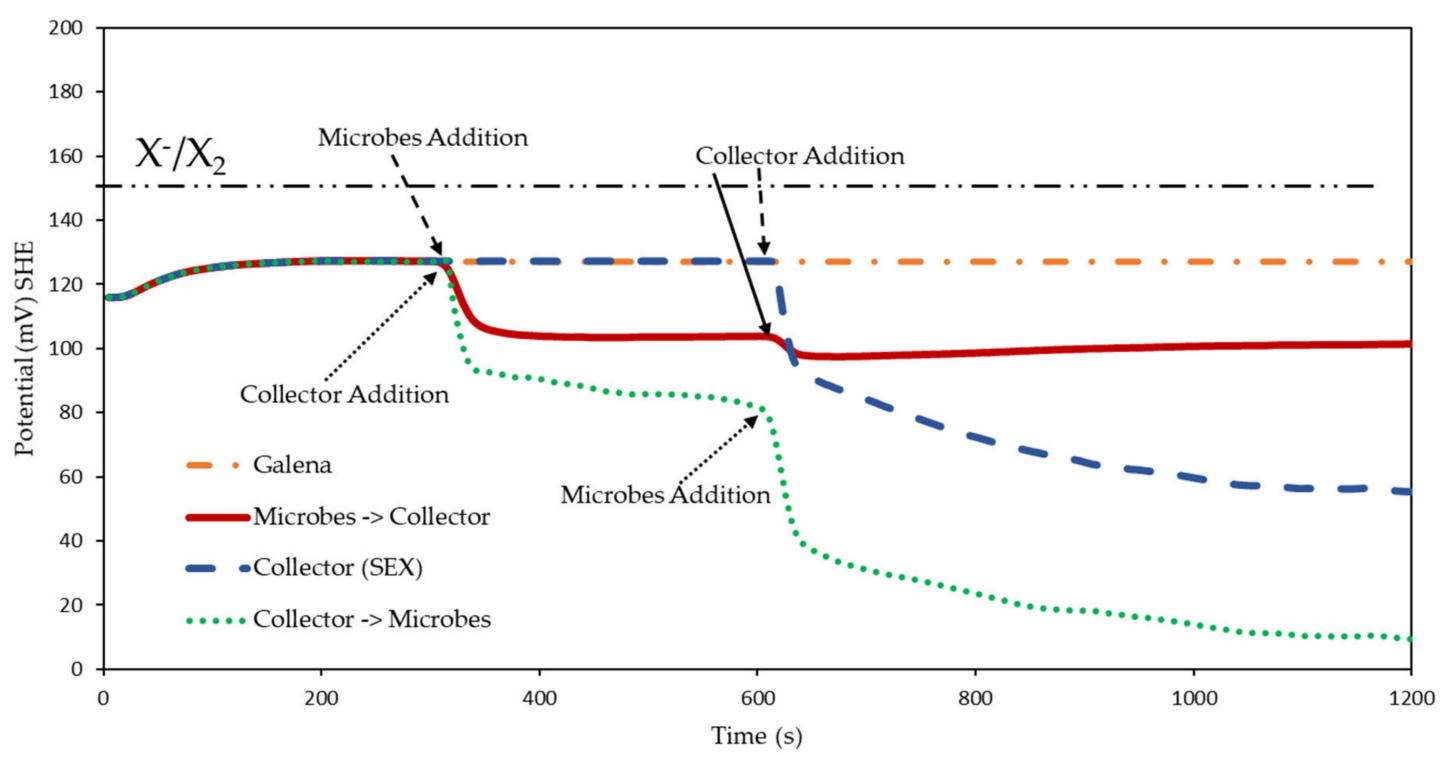

Figure 4. Mixed potential of galena in the presence of $2.4 \times 10^{-4} \mathrm{~mol} / \mathrm{L} \mathrm{SEX}, 1 \times 10^{8}$ cells $/ \mathrm{mL}$ microbes, $0.1 \mathrm{M} \mathrm{Na}_{2} \mathrm{SO}_{4}$ and $0.05 \mathrm{M} \mathrm{Na}_{2} \mathrm{~B}_{4} \mathrm{O}_{7}(\mathrm{pH} 9.3)$ at $25^{\circ} \mathrm{C}$.

The final mixed potential of chalcopyrite in the presence of SEX in Figure 3, is very close if not similar to that of the $\mathrm{X}^{-} / \mathrm{X}_{2}$ couple line, which exhibits a potential of $150 \mathrm{mV}$ as also reported by Tadie et al. [45]. This observation alludes to a possible coexistence of metal thiolate xanthate species and the dixanthogen species at the mineral surface. The drop in rest mixed potential when SEX was added, is indicative of an interaction between the SEX and the mineral surface and the subsequent gradual rise in potential could indicate conversion of initially chemisorbed xanthate into a metal thiolate complex on the mineral surface [45].The co-adsorption of dixanthogen and a metal thiolate on chalcopyrite has been previously discussed in the literature. Spectroscopy studies investigating xanthate interactions 
with chalcopyrite showed an initial layer of chemisorbed xanthate followed a secondary layer of co-adsorbed metal xanthate and physisorbed dixanthogen [46-48].

The addition of microbes at $300 \mathrm{~s}$ preceding collector addition, resulted in a negligible change, less than $10 \mathrm{mV}$, in mixed potential. Chandraprabha and Natarajan [49] similarly observed a weak response when the acidophilic sulphur oxidizing bacterium Acidithiobacillus thiooxidans was added to chalcopyrite. The weak interaction was attributed to the toxicity of copper ions on microbes which inherently resulted in poor adhesion efficiency. From Figure 3, the subsequent addition of SEX also does not result in any significant change in mixed potential. This result suggests that the microbes under investigation interacted weakly with the chalcopyrite in the period given for conditioning, however, the microbial presence on the mineral surface and solution was sufficient to reduce the interaction of SEX with chalcopyrite. The reverse sequence, the addition of SEX to the electrochemical cell followed by the addition of microbes, showed that once xanthate has adsorbed on chalcopyrite, the addition of microbes after $600 \mathrm{~s}$ did not result in any notable drop in mixed potential. Instead, the potential gradually rises from $145 \mathrm{mV}$ to $160 \mathrm{mV}$ over a period of $10 \mathrm{~min}$ ( $600 \mathrm{~s}$ to $1200 \mathrm{~s}$ ) where the conditioning was eventually stopped.

\subsubsection{Rest Potential Measurements for Galena in the Presence and Absence of Microbes}

Figure 4 illustrates the rest potential for the galena under different tests conditions. Galena in solution exhibited a rest potential of $130 \mathrm{mV}$ which dropped to $60 \mathrm{mV}$ in the presence of SEX. The final rest potential corroborates results obtained by Allison et al. [29], who showed a final rest potential of $60 \mathrm{mV}$ after $10 \mathrm{~min}$ of galena conditioning in the presence of $6.25 \times 10^{-4} \mathrm{M}$ SEX. Galena also exhibits a strong interaction with SEX as seen by the sharp drop in mixed potential. The final mixed potential of galena at all tested conditions is more negative when compared to chalcopyrite. This suggests that the galena mineral surface has greater reactivity towards oxidation. Consequently, the deviation of mixed potentials from that of other minerals may be due to additional oxidation on the mineral surface at lower potentials $[45,50]$. The addition of microbes preceding SEX addition to the system dampened the drop in mixed potential observed upon addition of the collector only. It can be inferred that the degree of collector interaction with the mineral decreases in the presence of microbes. The microbes likely passivate the mineral surface, thereby preventing effective collector adsorption on the mineral. In the reverse procedure, microbes still reduced the potential of the galena system even when collector had adsorbed. As seen in Figure 4, the mixed potential had not fully equilibrated when the microbes were introduced. It could be that the continuous drop in potential was due to the continued mineral oxidation under test conditions, the continued interaction of collector with the mineral surface, and the strong interaction between the microbes and galena. Since the final rest potentials of galena in the presence of microbes and collector lay below the $\mathrm{X}^{-} / \mathrm{X}_{2}$ couple's potential $(150 \mathrm{mV})$ as seen in Figure 4, it can be assumed that the likely adsorbed collector species present on the mineral's surface was the metal thiolate.

\subsubsection{Summary of Interaction Mechanisms in the Presence of Microbes}

The microbes in their time of interaction with both minerals (i.e., chalcopyrite and galena) did not alter the potential of the mineral surface enough to influence a change in the type of collector species present on the mineral surface. Another observation made relates to the perceived inability of microbes in decreasing mixed potentials on chalcopyrite once the collector had adsorbed. It is assumed that complexes formed by collector species on the chalcopyrite surface were not easily substituted from the surface by the addition of microbes. Surface cleaning of adsorbed collector species by microbes may not have been observed in the short interaction time investigated in this experiment and probably a similar case may prevail in a flotation circuit where residence time can be less than $1 \mathrm{~h}$. However, it must be borne in mind that long periods of interaction between microbes and collector may result in microbial consumption of xanthate in the pulp as part of the microbes' action, although, the majority of the consumed xanthate would probably be in the solution phase and not on the mineral surfaces per se. 
In order to explain the decrease in mixed potential over short periods as observed in the current studies, it is important to remember that for the sulphide mineral surface in solution, simultaneous reactions were occurring at the mineral. The microbes were adsorbing onto the mineral surface as the mineral surface was oxidizing. In both acidic and basic conditions galena is known to produce insoluble oxidation products on the mineral surface, creating an optimum surface prone to microbial attack. This increases the probability of microbial attachment on the mineral surface. In acidic conditions, galena is known to form an insoluble sulphate according to Equation (5), whereas in a basic medium lead hydroxide is formed according to Equation (6) [42].

$$
\begin{gathered}
\mathrm{PbS}+2 \mathrm{O}_{2} \rightarrow \mathrm{PbSO}_{4} \\
\mathrm{~Pb}^{2+}+2 \mathrm{OH}^{-} \rightarrow \mathrm{Pb}(\mathrm{OH})_{2}
\end{gathered}
$$

At the test conditions (i.e., basic medium), if the insoluble metal hydroxide forms, it can promote the enhanced affinity of microbial cells to galena possibly due to hydrogen bonding between hydroxyl groups within the structure of both the oxidized mineral surface and microbial cells. Leja [26] investigated the oxidation rates of sulphide minerals in basic conditions. The results supported that galena had faster oxidation rates in comparison to chalcopyrite. Surface oxidation under alkaline conditions such as those employed in this study led to the formation of thin lead hydroxide surface layers, which could facilitate the easier adsorption of microbes on the mineral surface. This theory plausibly explains (i) the fast decrease in mixed potential once galena was exposed to microbes in the electrochemical cell; and (ii) based on changes in minerals mixed potential before and after microbes were added to the electrochemical cell, there were stronger interactions between the microbes and galena in comparison to the interactions between microbes and chalcopyrite. Santhiya et al. [42] performed microbial adsorption tests employing Acidithiobacillus ferroxidans and showed that the microbes had a stronger affinity to galena compared to sphalerite, another sulphide mineral. Regarding ease of oxidation, galena oxidized much faster than sphalerite in basic conditions.

Bacterial cells at high concentrations and metabolic activity have been reported to limit the rate of oxygen transfer in solution [51]. As the mixed potential is based on coupled anodic and cathodic reactions occurring on the sulphide mineral surface, the marginal decrease in mixed potential when SEX and microbes interact with sulphide minerals may indicate the prevention of oxygen transfer across the interface. This hinders the progression of the cathodic oxygen reduction reaction. Microbes, when present in recycled plant waters or sewage water (raw or partially remediated), possess a strong bearing on flotation systems and may affect pulp redox potentials (Eh) and $\mathrm{pH}$, negatively influencing collector efficacy. Even in the short periods of contact between microbes present in recycled water from tailings ponds and minerals in the milling circuit, faster catalytic oxidation of minerals is possible. This oxidation is prevalent in acidic $\mathrm{pH}$ environments, at optimum temperatures around $40^{\circ} \mathrm{C}$. Acidic $\mathrm{pH}$ in tailing ponds water is easily attainable due to uncontrolled oxidation of sulphides in the tailings ponds and high temperatures are equally easily attained during grinding and milling [26].

\subsection{Microflotation Tests}

\subsubsection{Microflotation Tests on Chalcopyrite in the Presence of Microbes}

Changes in the isoelectronic points observed in this study suggest that the microbes within the MMC harvested from the South African platinum concentrator mine waters rendered the sulphide minerals hydrophilic. This hypothesis was further tested through microflotation tests. Figure 5; Figure 6 show the overall mineral recoveries obtained from microflotation tests conducted with chalcopyrite and galena, respectively. The microbe concentrations used in this study were informed by previous studies by Liu et al. [20] and Levay at al. [9]. From Figure 5, chalcopyrite recovery in the presence of SEX is high with an overall recovery of $83 \%$ achieved during the flotation period. Preconditioning with microbes alone at a microbial concentration of $4 \times 10^{8}$ cells $/ \mathrm{mL}$ results in a marked drop in 
chalcopyrite recovery. The addition of SEX after conditioning with microbes does not result in an increase in chalcopyrite recovery when compared to the microbe only test.

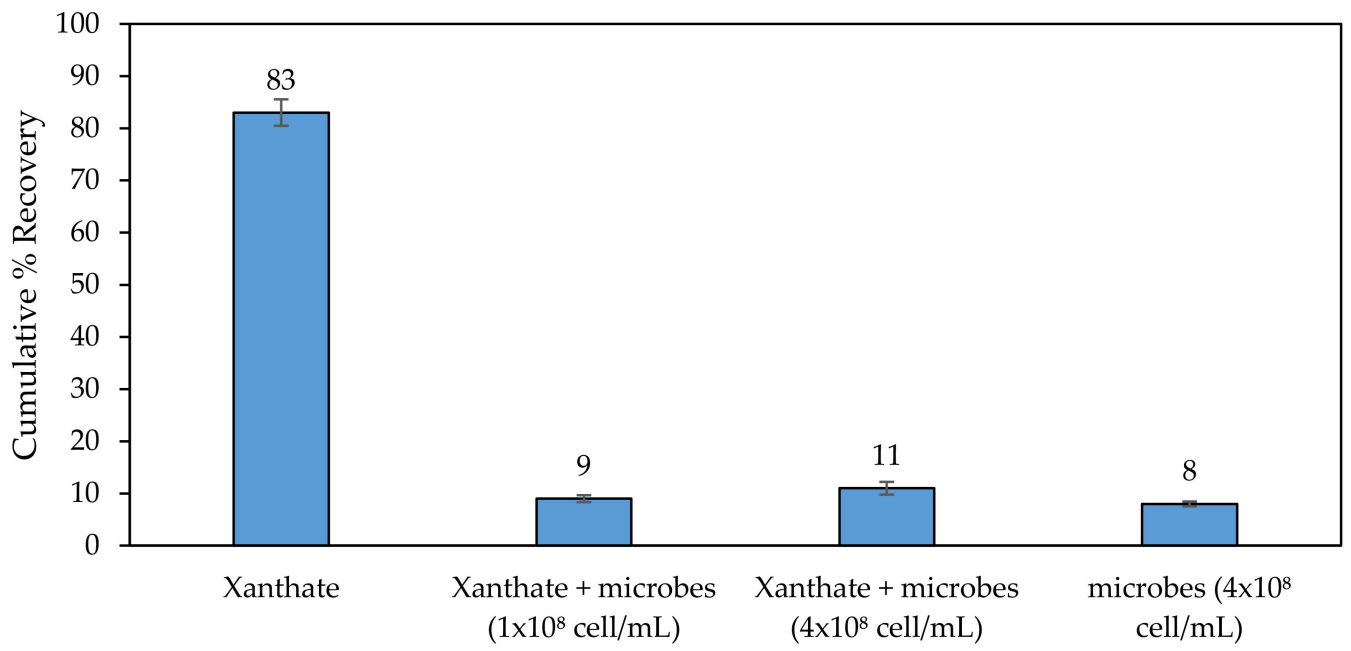

Solution Constituents

Figure 5. Chalcopyrite cumulative recoveries in the presence and absence of a $50 \%$ pseudo-monolayer SEX coverage and microbial cell counts of $1 \times 10^{8}$ cells $/ \mathrm{mL}$ and $4 \times 10^{8}$ cells $/ \mathrm{mL}$.

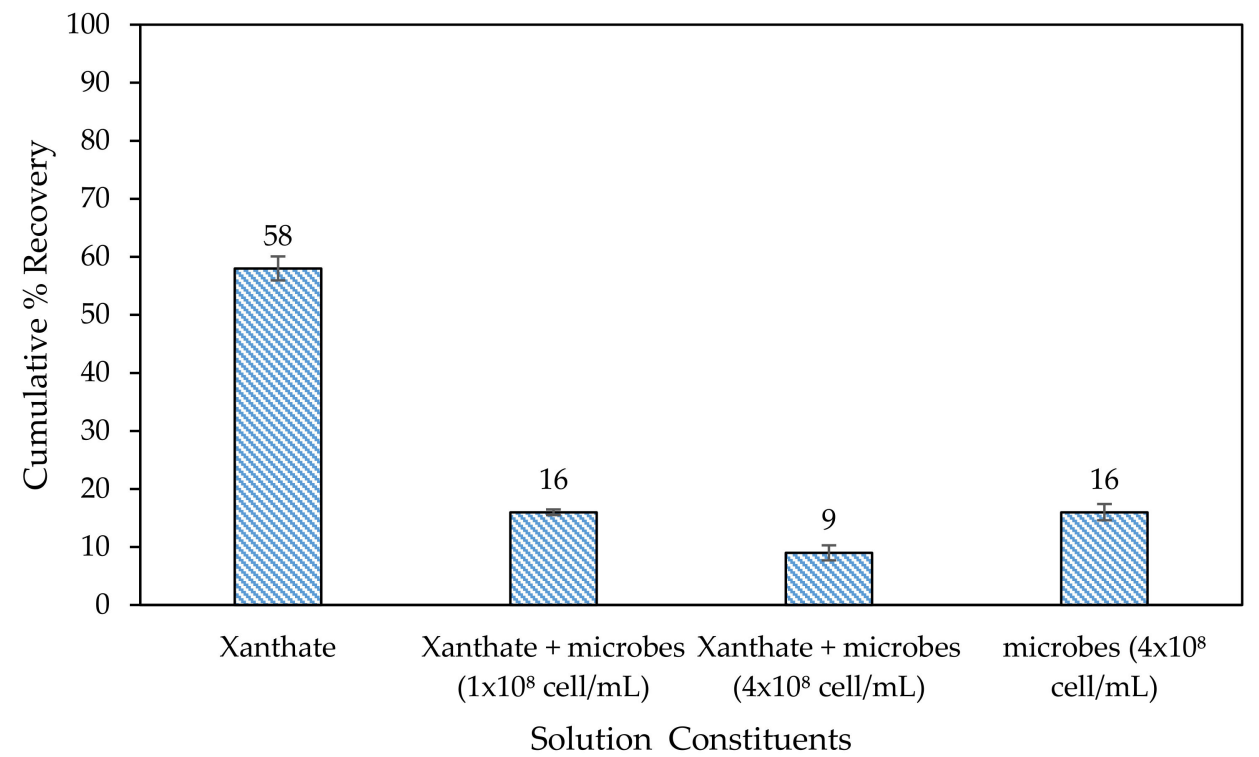

Figure 6. Galena cumulative recoveries in the presence of a 50\% pseudo-monolayer SEX coverage and microbial cell counts of $1 \times 10^{8}$ cells $/ \mathrm{mL}$ and $4 \times 10^{8}$ cells $/ \mathrm{mL}$.

\subsubsection{Microflotation Tests on Galena in the Presence of Microbes}

Figure 6 shows that galena recovery is also affected by the presence of microbes during the preconditioning stage. Galena recovery decreases from $59 \%$ to below $20 \%$ in the presence of microbes. The presence of both xanthate and microbes on the mineral surface seems to marginally increase depression of the mineral, when the microbial cell count is $4 \times 10^{8}$ cells $/ \mathrm{mL}$. The increased depression observed at the higher microbial cell concentration in the presence of SEX may be due to cell secretions released on the mineral's surface when microbes attach to mineral surfaces [43]. The interaction of these secretions with SEX can form complexes on the sulphide surface, increasing the mineral's hydrophilicity. 
A point of note in Figure 6 is the higher recovery of galena when microbes alone were employed during the preconditioning stage in comparison to when SEX was added to the microbes and galena during preconditioning using the same microbial concentration. As shown in Figure 7, during microflotation tests, excessive frothing was observed even in the absence of a synthetic frother. The result suggests that the microbes alone behaved as a bio-frother, however, the interactions of the microbes with xanthate at the air/liquid interface ruptured the bubbles thus reducing recovery when xanthate was present. This observation corroborates findings by Sharma and Rao [44]. Their work showed that maximum chalcopyrite and pyrite depression was attained at a microbial concentration of $1 \times 10^{7}$ cells $/ \mathrm{mL}$. Higher microbe concentration prompted mineral flotation resulting in similar recoveries in the presence and absence of collector, owing to excessive frothing within the flotation cell. Frothers are sensitive to the presence of collector molecules. Both reagents concentrate in layers at the solid/liquid interface and the air/liquid interface forming a thin film between the interfaces. The strength of this film influences formation of a mineral bubble aggregate. Excess collector concentrations result in a densely packed interface resulting in poor film penetration and mineral attachment [52,53]. There needs to be the correct balance between collector and frother concentrations to permit the correct mechanical properties of the film at the air/liquid interface in order to obtain good recoveries. A comprehensive study into microbially induced frothing in real ore systems using this microbial consortium will be explored in future studies.

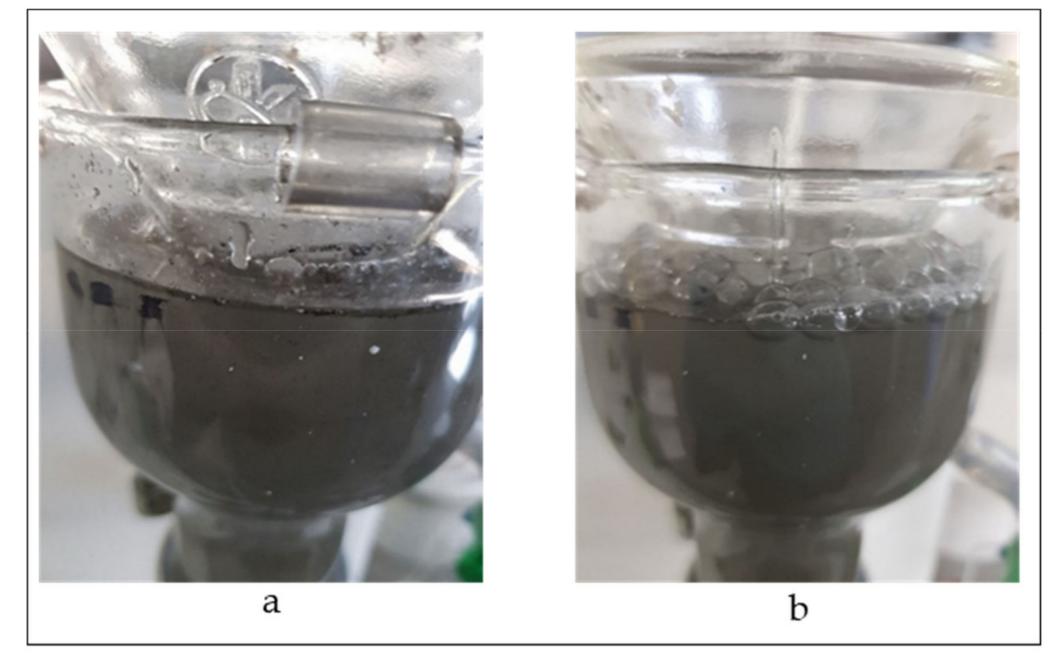

Figure 7. (a) Absence of frothing in the presence of a 50\% pseudo-monolayer SEX coverage and $4 \times 10^{8}$ cells $/ \mathrm{mL}$ of microbes. (b) Frothing effect observed in the presence of $4 \times 10^{8}$ cells $/ \mathrm{mL}$ of microbes without SEX.

\subsubsection{General Discussion of Microflotation Test Results}

It should be noted that the microflotation tests exclusively focused on pure minerals, hence there is a possibility of observing different flotation performance when a real ore is investigated in laboratory batch flotation or under plant conditions. In a synthetic mineral mixture or real ore where multiple minerals exist, microbial affinity towards the readily oxidized galena may take precedence over chalcopyrite, thereby limiting chalcopyrite depression. In addition, real ores are characterized by higher proportions of the electrochemically active mineral (e.g., pyrite or galena) in comparison to the concentration of the electrochemically noble mineral (e.g., chalcopyrite). Galvanic interactions between the noble and active minerals may result in the alteration of mineral surface properties thereby affecting flotation behaviour of both minerals [54,55]. Liu et al. [56], testing the effect of Escherichia.coli on flotation performance, noted a small decrease in flotation recovery rates of copper in real ore flotation tests compared to flotation tests using pure minerals. The authors attributed this result to microbial adhesion preference on pyrite amongst other minerals in addition to galvanic interactions 
between minerals. Consequently, the negative effect of microbes on chalcopyrite flotation recovery in a real ore was not as strong as is in pure mineral microflotation tests where galvanic interactions are absent. Furthermore, the differences in operating conditions and cell hydrodynamics, as the systems are changed from microflotation to batch flotation, cannot be overlooked.

\section{Conclusions}

Zeta potential measurements have shown that adhesion of microbes onto sulphide minerals occurred even when both the mineral surface and the microbes were negatively charged. It is suggested that microbial adhesion was based on hydrophobic interactions and enhanced adsorption onto fast oxidizing sulphides, such as galena, possibly due to a microbial affinity for hydroxide film on the mineral surface. Mixed potential studies successfully showed that microbes reduced the mixed potential on the sulphide mineral surface leading to a decrease in effective interaction between collector and minerals. The poor interaction of minerals and collectors in the presence of microbes could be a result of poor oxygen mass transfer in solution and at the solid/liquid interface. This limits the extent of oxidation-reduction reactions necessary for thiol collector attachment. The study has shown that when collectors adsorb on the chalcopyrite surface, first forming metal complexes on the surface, microbes had no influence on mineral surface mixed potentials.

Microflotation tests have shown that the mixed microbial community generally induced hydrophilicity on the surfaces of the sulphide minerals. This may be due to the presence of polysaccharides within microbial cultures which has previously been reported to induce mineral hydrophilicity. Currently we do not have insight into the microbial species representing the MMC used in this study. A survey of the 16S rRNA genes represented will be performed by Illumina amplicon sequencing and should shed further light on the interactions observed in this study. It must be noted that the negative effect on flotation observed in this study is not mutually exclusive. Depending on flotation conditions and ores, it is possible that the same microbes can behave differently.

Enhanced frothing in the presence of bacteria is expected for mineral processing plants using sewage and recycled water for flotation, as microflotation of sulphides revealed excessive frothing in the presence of microbes. To circumvent excessive frothing problems introduced by microbes (including their metabolic products and other water constituents) and inherently, poor concentrate grades due to excessive frothing, it may be necessary to optimize the reagent suite and dosages applied. In summary, it is necessary to work towards the implementation of suitable plant-based protocols to map the microbial load within all major water sources so that a suitable response in terms of altered plant operating conditions can be applied to prevent plant losses.

Author Contributions: Conceptualization, N.M., M.S., K.C. and N.S.; methodology, N.M; M.S. and K.C.; validation, N.M., M.S. and K.C.; formal analysis, N.M.; investigation, N.M.; resources, M.S., N.S. and K.C.; data curation, N.M.; writing-original draft preparation, N.M.; writing-review and editing, N.M., M.S., K.C. and N.S.; supervision, M.S., K.C. and N.S.; project administration, K.C. and N.S.; funding acquisition, K.C. and N.S. All authors have read and agreed to the published version of the manuscript.

Funding: This research received funding from the European Union H2020 programme under grant agreement no. 730480 .

Acknowledgments: The authors would like to acknowledge the Department of Bioproducts and Biosystems at Aalto University, the Centre for Minerals Research (CMR) at the University of Cape Town and the Centre for Bioprocess Engineering at the University of Cape Town for supporting this project.

Conflicts of Interest: The authors declare no conflicts of interest.

\section{References}

1. Dubel, J.; Smith, R.W.; Misra, M.; Chen, S. Microorganisms as Chemical Reagents: The Hematite System. Miner. Eng. 1992, 5, 547-556. [CrossRef]

2. Attia, Y.A.; Elzeky, M.; Ismail, M. Enhanced Separation of Pyrite from Oxidized Coal by Froth Flotation Using Biosurface Modification. Int. J. Miner. Process 1993, 37, 61-71. [CrossRef] 
3. Nagaoka, T.; Ohmura, N.; Saiki, H. A Novel Mineral Processing by Flotation Using Thiobacillus Ferrooxidans. Process. Met. 1999, 9, 335-342. [CrossRef]

4. Farahat, M.; Hirajima, T.; Sasaki, K. Adhesion of Ferroplasma Acidiphilum onto Pyrite Calculated from the Extended DLVO Theory Using the Van Oss-Good-Chaudhury Approach. J. Colloid Interface Sci. 2010, 349, 594-601. [CrossRef]

5. Slatter, K.; Plint, N.; Cole, M.; Dilsook, V.; de Vaux, D.; Palm, N.; Oostendorp, B. Water Management in Anglo Platinum Process Operations: Effects of Water Quality on Process Operations. In Proceedings of the International Mine Water Management Conference, Pretoria, South Africa, 19-23 October 2009; pp. 46-55.

6. Forssberg, K.S.; Hallin, M.I. Process water recirculation in a lead-zinc plant and Oter sulphide flotation plants. In Challenges in Mineral Processing; Sastry, K.V., Fuerstenau, M.C., Eds.; Society for Mining, Metallurgy and Exploration: Littleton, CO, USA, 1989; pp. 452-466.

7. Levay, G.; Schumann, R. A Systematic Approach to Water Quality Management in the Minerals Processing Industry. In Proceeding of Water in Mining Conference, Brisbane, Australia, 14-16 November 2006; pp. 277-287.

8. Cwalina, B.; Steindor, K. The Influence of Flotation Reagents on Sulfur-Oxidizing Bacteria: Acidithiobacilus Thiooxidans. Physicochem. Probl. Miner. Process. 2008, 42, 37-46.

9. Levay, G.; Smart, R.; Skinner, W. The Impact of Water Quality on Flotation Performance. J. S. Afr. Inst. Min. Metall. 2001, 1, 69-76.

10. Evdokimova, G.; Gershenkop, A.S.; Fokina, N. The Impact of Bacteria of Circulating Water on Apatite-Nepheline Ore Flotation. J. Environ. Sci. Heal. Part A Toxic/Hazardous Subst. Environ. Eng. 2012, 43, 398-404. [CrossRef]

11. Africa, C.J.; Van Hille, R.P.; Harrison, S.T.L. Attachment of Acidithiobacillus Ferrooxidans and Leptospirillum Ferriphilum Cultured under Varying Conditions to Pyrite, Chalcopyrite, Low-Grade Ore and Quartz in a Packed Column Reactor. Appl. Microbiol. Biotechnol. 2013, 97, 1317-1324. [CrossRef]

12. Sanhueza, A.; Ferrer, I.J.; Vargas, T.; Amils, R.; Sánchez, C. Attachment of Thiobacillus Ferrooxidans on Synthetic Pyrite of Varying Structural and Electronic Properties. Hydrometallurgy 1999, 51, 115-129. [CrossRef]

13. Yu, R.; Ou, Y.; Tan, J.; Wu, F.; Sun, J.; Miao, L.; Zhong, D. Effect of EPS on Adhesion of Acidithiobacillus Ferrooxidans on Chalcopyrite and Pyrite Mineral Surfaces. Trans. Nonferrous Met. Soc. China 2011, 21, 407-412. [CrossRef]

14. Crundwell, F.K. How Do Bacteria Interact with Minerals? Hydrometallurgy 2003, 71, 75-81. [CrossRef]

15. Leduc, D.; Leduc, L.G.; Ferroni, G.D. Quantification of Bacterial Populations Indigenous to Acidic Drainage Streams. Water. Air. Soil Pollut 2002, 135, 1-21. [CrossRef]

16. Deo, N.; Natarajan, K.A.; Somasundaran, P. Mechanisms of Adhesion of Paenibacillus Polymyxa onto Hematite, Corundum and Quartz. Int. J. Miner. Process 2001, 62, 27-39. [CrossRef]

17. Blake, R.C.; Shute, E.A.; Howard, G.T. Solubilization of Minerals by Bacteria: Electrophoretic Mobility of Thiobacillus Ferrooxidans in the Presence of Iron, Pyrite, and Sulfur. Appl. Environ. Microbiol. 1994, 60, 3349-3357. [CrossRef]

18. Solari, J.A.; Huerta, G.; Escobar, B.; Vargas, T.; Badilla-Ohlbaum, R.; Rubio, J. Interfacial Phenomena Affecting the Adhesion of Thiobacillus Ferrooxidans to Sulphide Mineral Surface. Colloids Surf. 1992, 69, 159-166. [CrossRef]

19. Rao, M.K.; Somasundaran, P.; Schilling, K.M.; Carson, B.; Ananthapadmanabhan, K.P. Bacterial Adhesion onto Apatite Minerals_Electrokinetic Aspects. Colloids Surf. A Physicochem. Eng. Asp. 1993, 79, $293-300$. [CrossRef]

20. Liu, W.; Moran, C.J.; Vink, S. Mechanism Study of the Impact of Water-Borne Bacteria on Flotation. Int. J. Miner. Process. 2013, 123, 39-45. [CrossRef]

21. Zobell, C.E. The Effect of Solid Surfaces upon Bacterial Activity1. J. Bacteriol. 1943, 46, 39-56. [CrossRef]

22. Woods, R. The Oxidation of Ethyl Xanthate on Platinum, Gold, Copper, and Galena Electrodes. Relation to the Mechanism of Mineral Flotation. J. Phys. Chem. 1971, 75, 354-362. [CrossRef]

23. Hu, Y.; Sun, W.; Wang, D. Electrochemistry of Flotation of Sulphide Minerals; Springer: Beijing, China, 2009; pp. 63-111.

24. Bozkurt, V.; Xu, Z.; Finch, J.A. Pentlandite/Pyrrhotite Interaction and Xanthate Adsorption. Int. J. Miner. Process. 1998, 52, 203-214. [CrossRef] 
25. Trahar, W.J.; Guy, P.J. The effects of oxidation and mineral interaction of sulphide flotation. In Flotation of Sulphide Minerals; Forssberg, K.S., Ed.; Elsevier B.V.: Amsterdam, The Netherlands, 1985; pp. 91-110.

26. Leja, J. Surface Chemistry of Froth Flotation; Plenum Press: New York, NY, USA, 1982; pp. 341-432.

27. Rao, S. Collector Mechanism I. Thiol collectors in sulfide minerals. In Surface Chemistry of Froth Flotation; Springer: Boston, MA, USA, 2004; pp. 479-526.

28. Buswell, A.M.; Bradshaw, D.J.; Harris, P.J.; Ekmekci, Z. The Use of Electrochemical Measurements in the Flotation of a Platinum Group Minerals (PGM) Bearing Ore. Miner. Eng. 2002, 15, 395-404. [CrossRef]

29. Allison, S.A.; Goold, L.A.; Nicol, M.J.; Granville, A. Determination of the Products of Reaction between Various Sulfide Minerals and Aqueous Xanthate Solution, and a Correlation of the Products with Electrode Rest Potentials. Met. Trans. 1972, 3, 2613-2618. [CrossRef]

30. Pesic, B.; Oliver, D.J.; Wichlacz, P. An Electrochemical Method of Measuring the Oxidation Rate of Ferrous to Ferric Iron with Oxygen in the Presence of Thiobacillus Ferrooxidans. Biotechnol. Bioeng. 1989, 33, 428-439. [CrossRef] [PubMed]

31. Holmes, P.R. The Mechanism of Bacterial Action in the Leaching of Pyrite by Thiobacillus Ferrooxidans. An Electrochemical Study. J. Electrochem. Soc. 1999, 146, 2906. [CrossRef]

32. Fowler, T.A.; Holmes, P.R.; Crundwell, F.K. On the Kinetics and Mechanism of the Dissolution of Pyrite in the Presence of Thiobacillus Ferrooxidans. Hydrometallurgy 2001, 59, 257-270. [CrossRef]

33. Taguta, J.; O'Connor, C.T.; McFadzean, B. The Effect of the Alkyl Chain Length and Ligand Type of Thiol Collectors on the Heat of Adsorption and Floatability of Sulphide Minerals. Miner. Eng. 2017, 110, 145-152. [CrossRef]

34. Grano, S.R.; Prestidge, C.A.; Ralston, J. Solution Interaction of Ethyl Xanthate and Sulphite and Its Effect on Galena Flotation and Xanthate Adsorption. Int. J. Miner. Process 1997, 52, 161-186. [CrossRef]

35. Wiese, J.; Harris, P.; Bradshaw, D. The Influence of the Reagent Suite on the Flotation of Ores from the Merensky Reef. Miner. Eng. 2005, 18, 189-198. [CrossRef]

36. Manono, M.S.; Corin, K.C.; Wiese, J.G. The Influence of Electrolytes Present in Process Water on the Flotation Behaviour of a Cu-Ni Containing Ore. Miner. Eng. 2016, 96-97, 99-107. [CrossRef]

37. Tadie, M.; Corin, K.C.; Wiese, J.G.; O'Connor, C.T. Electrochemical Interactions of Platinum Group Minerals with Copper Sulphate. Miner. Eng. 2017, 112, 43-49. [CrossRef]

38. Bradshaw, D.J.; Connor, C.T. Measurement of the Sub-Process of Bubble Loadin in Flotation. Miner. Eng. 1996, 9, 443-448. [CrossRef]

39. Elmahdy, A.M.; El-Mofty, S.E.; Abdel-Khalek, N.A.; El-Midany, A.A. Impact of the Adsorption of Corynebacterium Diphtheriae Intermedius Bacteria on Enhancing the Separation Selectivity of Dolomite and Apatite. Adsorpt. Sci. Technol. 2011, 29, 47-58. [CrossRef]

40. Sharma, P.K.; Rao, K.H.; Forssberg, K.S.E.; Natarajan, K.A. Surface Chemical Characterisation of Paenibacillus Polymyxa before and after Adaptation to Sulfide Minerals. Int. J. Miner. Process 2001, 62, 3-25. [CrossRef]

41. Gu, G.H.; Hu, K.T.; Li, S.K. Surface Characterization of Chalcopyrite Interacting with Leptospirillum Ferriphilum. Trans. Nonferrous Met. Soc. China 2014, 24, 1898-1904. [CrossRef]

42. Santhiya, D.; Subramanian, S.; Natarajan, K.A. Surface Chemical Studies on Galena and Sphalerite in the Presence of Thiobacillus Thiooxidans with Reference to Mineral Beneficiation. Miner. Eng. 2000, 13, 747-763. [CrossRef]

43. Rijnaarts, H.H.M.; Norde, W.; Lyklema, J.; Zehnder, A.J.B. The Isoelectric Point of Bacteria as an Indicator for the Presence of Cell Surface Polymers That Inhibit Adhesion. Colloids Surf. B Biointerfaces 1995, 4, 191-197. [CrossRef]

44. Sharma, P.K.; Rao, K.H. Role of a Heterotrophic Paenibacillus Polymyxa Bacteria in the Bioflotation of Some. Sulfide Miner. 2000, 16, 35-41.

45. Tadie, M.; Corin, K.C.; Wiese, J.G.; Nicol, M.; O'Connor, C.T. An Investigation into the Electrochemical Interactions between Platinum Group Minerals and Sodium Ethyl Xanthate and Sodium Diethyl Dithiophosphate Collectors: Mixed Potential Study. Miner. Eng. 2015, 83, 44-52. [CrossRef]

46. Fuerstenau, M.C.; Chander, S.; Woods, R. Froth flotation. In Froth Flotation: A Century of Innovation; Fuerstenau, M.C., Jameson, G., Yoon, R., Eds.; Society for Mining, Metallurgy and Exploration: Littleton, CO, USA, 2007; pp. 425-465.

47. Bowden, J.L.; Young, C.A. Xanthate Chemisorption at Copper and Chalcopyrite Surfaces. J. S. Afr. Inst. Min. Met. 2016, 116, 503-508. [CrossRef] 
48. Mielczarski, J.A.; Mielczarski, E.; Cases, J.M. Interaction of Amyl Xanthate with Chalcopyrite, Tetrahedrite, and Tennantite at Controlled Potentials. Simulation and Spectroelectrochemical Results for Two-Component Adsorption Layers. Langmuir 1996, 12, 6521-6529. [CrossRef]

49. Chandraprabha, M.N.; Natarajan, K.A. Surface Chemical and Flotation Behaviour of Chalcopyrite and Pyrite in the Presence of Acidithiobacillus Thiooxidans. Hydrometallurgy 2006, 83, 146-152. [CrossRef]

50. Somasundaran, P.; Nagaraj, D.R. Chemistry and Applications of Chelating Agents in Flotation and Flocculation. In Reagents in Mineral Industry; Jones M.J., Oblatt R., Eds.; Springer: London, UK, 1984; pp. 209-219.

51. Galaction, A.I.; Cascaval, D.; Oniscu, C.; Turnea, M. Prediction of Oxygen Mass Transfer Coefficients in Stirred Bioreactors for Bacteria, Yeasts and Fungus Broths. Biochem. Eng. J. 2004, 20, 85-94. [CrossRef]

52. Manev, E.; Pugh, R.J. Frother/Collector Interactions in Thin Froth Films and Flotation. Colloids Surf. A Physicochem. Eng. Asp. 1993, 70, 289-295. [CrossRef]

53. Bradshaw, D.J.; Harris, P.J.; O'Connor, C.T. Synergistic Interactions between Reagents in Sulphide Flotation. J. S. Afr. Inst. Min. Metall. 1998, 98, 187-192.

54. Ekmekçi, Z.; Demirel, H. Effects of Galvanic Interaction on Collectorless Flotation Behaviour of Chalcopyrite and Pyrite. Int. J. Miner. Process. 1997, 52, 31-48. [CrossRef]

55. Rao, Y.M.K.; Natarajan, K.A. Electrochemical Effects of Mineral-Mineral Interactions on the Flotation of Chalcopyrite and Sphalerite. Int. J. Miner. Process 1989, 27, 279-293. [CrossRef]

56. Liu, W.; Moran, C.J.; Vink, S. Impact of Chalcopyrite Depression by Water-Borne Bacteria in Pure and Combined Mineral Systems. Int. J. Miner. Process. 2013, 123, 18-24. [CrossRef]

(C) 2020 by the authors. Licensee MDPI, Basel, Switzerland. This article is an open access article distributed under the terms and conditions of the Creative Commons Attribution (CC BY) license (http://creativecommons.org/licenses/by/4.0/). 